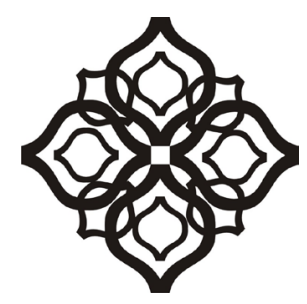

Shirkah

Journal of Economics and Business 


\section{Shirkah}

Journal of Economics and Business

Vol. 4, No. 2, May-August 2019

ISSN: 2503-4235 (p); 2503-4243 (e)

\section{Editor in Chief}

Fitri Wulandari

\section{Managing Editor}

Jasanta Peranginangin

\section{Editorial Boards}

AAbdul Azim Islahi,

Islamic Economics Institute, King Abdulaziz University, Saudi Arabia

Abu Umar Faruq Ahmad,

UBD School of Business and Economics Universiti, Brunei Darussalam

Cedomir Nestorovic,

ESSEC Business School Asia Pacific, Singapore

Johan Fischer,

Department of Social Sciences and Business Roskilde Universitetscenter, Denmark Muhamed Zulkhibri,

Islamic Research and Training Institute, Islamic Development Bank, Saudi Arabia M. Kabir Hassan,

Department of Economics and Finance, University of New Orleans, United States Musa Asy'arie,

Faculty of Islamic Economics and Business, IAIN Surakarta, Indonesia

Nunung Nurul Hidayah,

Aston Business School, Aston University, Birmingham, United Kingdom

Saim Kayadibi,

Department of Economics, Kulliyyah of Economics and Management Science,

International Islamic University Malaysia, Malaysia

Shaikh M Ghazanfar,

Departement of Economics, University of Idaho, Russian Federation 
Sigit S. Wibowo,

Department of Management, Faculty of Economics and Business, Universitas Indonesia, Indonesia

Vihang R. Errunza,

Desmarais Global Finance Research Centre, Desautels Faculty and Management, McGill University, Canada

\section{Assistant to Editor}

M. Endy Saputro

M. Zainal Anwar

Shirkah Journal of Economics and Business is a peer-reviewed journal published three times a year (January-April, May-August and September-December) by Faculty of Islamic Economics and Business, Institut Agama Islam Negeri (IAIN) Surakarta Central Java, Indonesia. The main objective of Shirkah is to offer an academic space of exchange ideas and initiate the increase number of qualified article produced by postgraduate students, practitioners and academicians.

\section{Editorial Office}

Ruang Jurnal Shirkah

Lantai Dasar, Sayap Barat, Fakultas Ekonomi dan Bisnis Islam, IAIN Surakarta

Jln. Pandawa No. 1, Kartasura, Sukoharjo, Jawa Tengah Kode Pos. 57168

Phone (+62271) 781516 Fax: (+62271)782336

E-mail: shirkahjournal@iainsurakarta.ac.id; shirkahiainsurakarta@gmail.com Website: http://shirkah.or.id/ 


\section{Shirkah}

Journal of Economics and Business

Vol. 4, No. 2, May-August 2019

ISSN: 2503-4235 (p); 2503-4243 (e)

\section{Table of Contents}

\section{Articles}

Abd Hannan

Santripreneurship and Local Wisdom Economic Creative of Pesantren Miftahul Ulum

Muh. Salahuddin

Nurhilaliati

Zaenal Arifin

Entrepreneurship and Economics of Pesantrens in Lombok Island

Abdul Jalil

Alumni Networks and Economic Reinforcement in Pesantren

Ummussabri

Jehan Maya Zayanie

Ahsana Fitria

Rosidatul Kamariah

Bank Wakaf Mikro and Creative Economics in Pesantren Buntet

Farihatul Qamariyah

Muslim Business Women in Indonesia

Fachrurazi

Dwi Srya Atmaja

Zaenuddin Hudi Prasojo

Muslim Businessmen and Chinese Economics in Singkawang 


\title{
Bank Wakaf Mikro and Creative Economics in Pesantren Buntet
}

\author{
Jehan Maya Zayanie \\ Islamic Economics, Graduate School, Universitas Islam Negeri Syarif Hidayatullah \\ Jakarta \\ Jeymaya120594@gmail.com \\ Ahsana Fitria \\ Islamic Economics, Graduate School, Universitas Islam Negeri Syarif Hidayatullah \\ Jakarta \\ ahsafitri0814@gmail.com \\ Rosidatul Kamariah \\ Islamic Economics, Graduate School, Universitas Islam Negeri Syarif Hidayatullah \\ Jakarta \\ rosida2012.alkhamarye@gmail.com
}

\begin{abstract}
The launch of the Bank Wakaf Mikro (Micro Wakaf Bank/BWM) at the pesantren by the Financial Services Authority $(\mathrm{OJK})$ has received a positive response to realize economic opportunities in the pesantren. This study aims to examine the role of pesantren in empowering the creative economics through the BWM program. This study was conducted through doing in-depth observations and interviews. The researchers gathered data using purposive sampling and snowball sampling techniques. The research findings illustrate the presence of BWM at the pesantren Buntet, Cirebon, West Java, Indonesia has provided a new forum, both for the leaders of the pesantren and the community around the pesantren to carry out their economic potential. Communities surrounding the pesantren argue that BWM has been able to overcome the difficulties in accessing financing needs on a micro scale. However, the BWM needs to increase the amount of funding and products to follow customers' needs in order to create more promising business variations.
\end{abstract}

Keywords: pesantren, OJK, micro bank, Buntet, Cirebon 


\section{Introduction}

Pesantren, as a unique character of Islamic education in Indonesia, has a strategic role in educating Islamic values in everyday life, called tafaqquh fiddin by emphasizing the importance of morality in society (Mastuhu, 1994). This institution has played an important role in the spread of Islam in Indonesia. This institution also has become a means of formal socialization through teaching. It should be noted that pesantren maintain the oldest scientific tradition in Indonesia and other Malay regions (Turmudi, 2006). The role of pesantren as an educational institution whose focus is on spreading religion has become a deeper value in the economic development of the people, especially the Islamic economics. Pesantren has established themselves as the center of the Islamic development movement. This has been confirmed by Dhofir (1982) that the pesantren institution has a major influence in determining Islamic character.

According to Madekhan (2017), pesantren has become one of the elements of society that has a strategic function in mentoring to encourage the economics of the community. The role of pesantren in the economic development of the society will be strong in order to encourage economic growth, equal income, alleviate poverty and achieve financial system stability. Within Muslim societies, poverty has spread widely because poor people have been excluded from the financial system due to the fact that their inability to keep up with economic development. However, this condition is getting better because Islamic microfinance gets in line with a growing market with a comprehensive approach to human empowerment (Bakar et all, 2016). Along with the implementation of economic activities, pesantren can be a way to realize the functions of financial institutions, especially the alleviation of poverty and economic inequality in Indonesia. Based on statistical data in 2017, poverty and inequality are still a significant problem for the nation. At present, the 
number of poor people in Indonesia is 26.6 million or around 10.12\%, followed by high inequality, which is at the level of 0.3910 with the largest imbalance coming from the city at 0.4040 . It is also stated that almost all regions in Indonesia tended to have a poverty rate of $12-28 \%$ or above the national average. With these conditions, the presence of pesantren can play a role in the economic empowerment as the solutions in alleviating inequality and poverty.

Much have been carried out on pesantren, yet mostly analyzing it from the educational, social and political dimensions. There were only small number of researches focusing on economic potential of the pesantren (Nadzir, 2015). The total number of pesantrens in Indonesia is 25,938 institutions based on Pesantren Database (PDPP). This number has enormous potential in the economic field, but has not been much noticed, either by the government or the pesantren itself. The pesantren is now expected to not only play its traditional functions, as Azra (2012) wrote, for "the transmission and transfer of Islamic sciences, the maintenance of Islamic traditions, the reproduction of ulama" but also become a center for health education, the development of appropriate technology for rural communities, the environment preservation and the economic empowerment of the community. Pesantren can act as an intermediary institution for empowering human resources (Haidari, 2004). According to Nadzir (2015), economic empowerment activities are a form of da'wa preaching and the implementation of pesantren knowledge. In addition, ongoing economic empowerment is expected to bring economic growth.

The development of Indonesia's creative economics is a form of optimism and overflowing aspirations to support realizing Indonesia's vision of becoming a developed country. There are thoughts, ideals, imagination, and dreams to become a society with a prosperous quality of life (Ministry of Religion, 2008). The creative economic system is 
believed to overcome these economic problems, as well as an alternative in facing the challenges of the global economy. Indonesia which is rich in culture and has a large population has enormous potential in developing the creative economy. Alvin Toffler in his theory has divided the wave of economic civilization into three waves. First, the wave of agricultural economy. Second, the wave of the industrial economy. Third, the wave of information economy. Based on predictions, then the fourth wave will come, namely the wave of creative economics oriented towards creative ideas and ideas (Noviyanti, 2017).

Seeing the potential of pesantren as the economic center of rural communities with many micro, small and medium enterprises, which are forms of economic organization that are in harmony with society's economic program supported by a community structure with the lives of santri who live in pesantren, the role of very strong figures and rural communities who are in boarding schools that are still classified as poor and far from access to capital The relationship of the kyai and its people is based on mutual expectations. Community members usually expect clerics to give them spiritual, moral and religious guidance, and play a protective leadership role. As a result, the community respected the kyai, so that the kyai gained moral authority to spread the teachings of Islam in the community including in introducing creative economies in their pesantren environment (Isbah, 2016).

The message delivered in the assembly meeting is not always related to worshiping god, but also covers daily life and social problems faced by the community. In this case, the kyai can be an actor in conveying ideas of social change to his community through his agency (Eka, 2012). In order to eliminate economic disparity between the rich and the poor, this effort can be minimized through maximizing the empowerment of micro-enterprises. For this reason, access to capital is needed evenly for the 
small and medium-sized community through government programs by establishing Islamic boarding-based Islamic Financial Institutions (LKMS) with funding from donors with endowments called waqf, this is a form of government efforts to develop the creative industry with the hope of further enhancing the ability of innovation and adaptability that has been built naturally (Moelyono, 2010). The President embodies the establishment of the LKMS as the Bank Wakaf Mikro (BWM/Micro Wakaf Bank) for which OJK facilitated its sharia business model (BPRS) or existing Wakaf Agency. In October 2017, President Joko Widodo (Jokowi) inaugurated BWM of Pesantren Kempek and Buntet.

Figure 1. Percentage of Creative Economic Enterprises

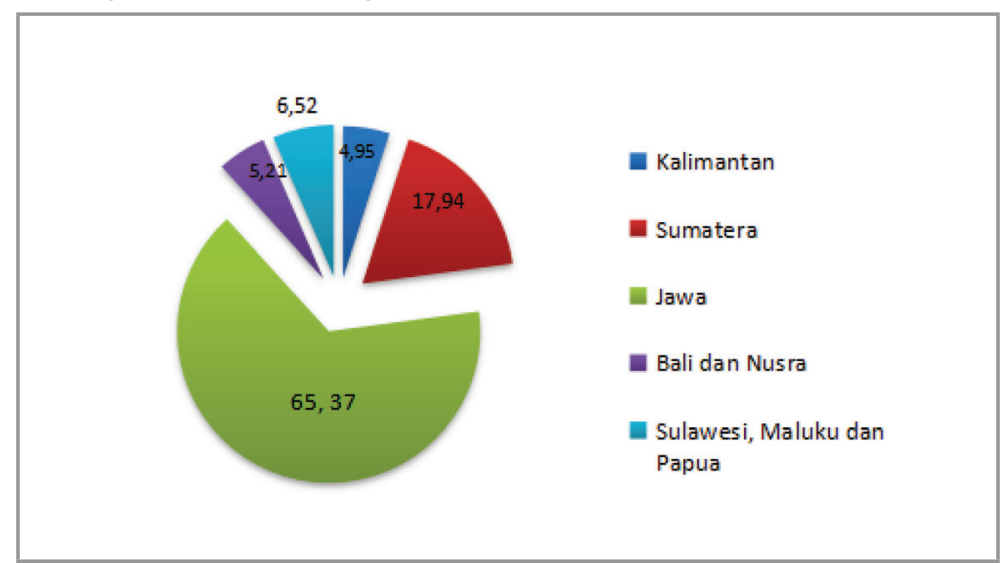

Source: Economic Census of the Central Bureau of Statistics, 2016.

Based on the percentage of creative economy efforts above, Java Island gets the highest value with 65.37 out of a total of $99.99 \%$ compared to other islands throughout Indonesia. This is a big reason BWM was first established on the island (Central Statistics Agency and Be Kraf, 2016). OJK will continue to encourage the establishment of BWM to pesantrens and other communities throughout Indonesia, which are expected to be 
an accelerator of sharia financial development and encourage increased equity and welfare of the community. Wimboh Santoso says that BWM has been placed in pesantren because the pesantren has existed with the formation of the ummah. Usually education in pesantren covers only the spiritual aspects, but not life entrepreneurship. The President adds that putting BWM in pesantrens also provides opportunities for students to learn the management of a banking professionally, if this BWM run the greater the economy of the people can run well (Widodo, 2018).

In October 2017, President Joko Widodo (Jokowi) inaugurated several BWMs located on Java, namely the KHK Kempek BWM and the BWM Pesantren Buntet Cirebon. In this study, we focus on the BWM of pesantren Buntet which until March 2019 has been running for 17 months. This BWM specifically targets the community around the boarding school environment to provide capital services to be able to start or develop their small business. However, we found that not all communities around the pesantren knew about their BWM and its functions. Some people felt they were not familiar with this institution. Therefore, we analyze the role and development of BWM that has been running, and how BWM contributes to realizing all the potential of creative economy in the pesantren environment. We argue that has played a significant role in improving the welfare of its customers, but this development must be supported by the innovation of the BWM program

\section{Profile of the Pesantren Buntet}

Pesantren Buntet is one of the oldest pesantren in Indonesia which was founded in 1750 AD by KH. Muqoyyim bin Abdul Hadi. The pesantren is located between two villages, namely Mertapada Kulon and Mujul. The existence of Buntet boarding schools is quite unique because of its homogeneous community; between santri and native people 
of pesantren is difficult to distinguish. In addition, this pesantren has passed seven periods with a total of 56 pesantrens with more than 5000 students under the Buntet Pesantren Foundation (YLPI) Foundation. The relationship between one and other pesantrens is still led by a big family of pesantren. Therefore, the kinship between all pesantrens is still very strong. The education system that runs in the Pesantren Buntet is traditional and modern.

The presence of the pesantren is the main attraction for the community and the government because it has economic potential that can be developed by the community around the pesantren. This also prompted the Financial Services Authority $(\mathrm{OJK})$ as a government institution to offer the pesantren to establish a BWM program. The pesantren has fulfilled several selection criteria for the establishment of the initial BWM project in each regional representative seen from certain aspects, including many influential santri, and having good cooperative relations between OJK and the pesantren. The selection process is carried out directly with a survey from the OJK to the markets around the pesantren which are considered potential. Based on the environmental survey and the surrounding economic situation, it was concluded that the pesantren was quite potential for the establishment of BWM. The establishment of BWM was confirmed by the statement of Ustadz Aji as manager of the BWM in Buntet. He said, "Finally we received program assistance from OJK for the establishment of BWM, because this program is good and very helpful in micro-scale economics." Ustadz Agus Nasrullah, a chairman of BWM of the Pesantren Buntet added, "Out of the initial 20 BWM pilot projects, Buntet was included in the top 10 , because of the administrative process, the legality of formal education institutions, the completeness of the letter from Menkumham, the composition of the board and notaries, all of which were registered and legal." 


\section{BWM Pesantren Buntet}

BWM is under the authority of Yayasan Lembaga Pendidikan Islam (YLPI) Pesantren Buntet led by Ustadz Agus Nasrullah who is also the leader of the Pesantren Al-Hikmah and Al-Inaroh. The BWM of the Pesantren Buntet was approved in October 2017 along with the ratification of the BWM Kempek which was held at the Cirebon by the President of the Republic of Indonesia. After more than a year, BWM Pesantren Buntet has developed. Based on the results of field observations, up to the end of February 2019 the total number of customers that have been funded by the BWM reached 500 people and up to now customers are being funded as many as 285 people with a total funding of Rp. 200,000,000, and a total return of $100 \%$.

In term of organizational managerial aspect, this BWM consists of administrators and managers. The management structure of BWM does not only involve people who have expertise in their fields, but santri graduated from pesantren also play an important role. They served as BWM Pesantren Buntet supervisors who were trusted to assist customers every week, lead the running of weekly halaqah (HALMI) and repay financing. In addition to teaching religious knowledge, the pesantren Buntet provides opportunities for students who have economic potential to develop their abilities through BWM programs. The BWM also affords opportunities for students, both santri boarding schools or other students to take part in an internship program at BWM. This aims to train santri to be ready to carry out the process of empowerment and mentoring for people who receive benefits.

The customers are small traders who want to improve their economics. Those who will be given capital must first go through various stages to avoid the risk of financing. The initial stage begins with a survey of prospective customers for due diligence, knowing the basic character 
and characteristics of individual prospective customers. Before becoming a customer, they were formed in a core group called KUMPI (Collection of Indonesian Productive Micro Enterprises) consisting of at least 5 people to take part in Compulsory Group Training (PWK) for 5 consecutive days. The next stage, after joining PWK, a group will be formed with a weekly halaqoh name (HALMI) consisting of 3-5 KUMPI. The first HALMI meeting will be disbursed. Then a week later HALMI at the second meeting was filled with associations in religious education, business development and household economic management as well as repayment of installments (the Financial Service Authority, 2018).

The schedule of HALMI meeting is held on Monday to Thursday, while Friday is used for practical steps to anticipate actions in the event of bad credit or the fulfillment of urgent operational activities. The BWM financing return system applies a joint liability and repayment system every week at HALMI with a pick-up system, namely the supervisor comes to HALMI and leads the running of HALMI. At present, the supervisor of the BWM consists of two people, Mr. Aem oversees nine HALMI with 29 KUMPI with a total number of 115 people, while Mr. Aan, a santri, who be responsible as a BWM manager oversees 10 HALMI and 36 KUMPI with 170 customers in total. Thus, the total number of customers funded by the BWM of the pesantren Buntet is 285 people.

The BWM distributes financing in the form of business capital to the community ranging from Rp. 1,000,000, - Rp. 3,000,000 without collateral and profit-sharing margins equal to 3 percent with a payback tenor of 50 or 25 weeks. The amount of Rp.1,000,000 is the initial financing and is only given to prospective customers who have passed the training for 5 days. The training was conducted for the initial screening of prospective customers before receiving funding. The tenor of time for financing is Rp. 1,000,000 can be done with two choices, 50 weeks with a 
return amount of Rp. 20,000 / week and 25 weeks with a refund amount of IDR 40,000/ week. Customers who have paid off the first financing and want to be funded again will be given additional funding provided that the customer is diligent and disciplined in participating in HALMI and is not stuck in returning the financing. Customers who fulfill these requirements are entitled to get an additional financing worth 2,000,000 with two choices of time, namely 50 weeks with a return amounting to Rp. 40,000/ week and 25 weeks with a refund amount of Rp. 60,000/ week. However, if the attendance value of HALMI is less than 75 percent, then the maximum funding provided is still Rp. 1,000,000.

Along with the initial capital provided by BWM, customers can only use the business in a small scale, such as the warteg (traditional restaurant) or ketoprak (Indonesian salad with peanut sauce), fried rice, breakfast snacks and other small businesses. BWM assumes that with small capital but for the lower classes, it can be used productively to increase income and welfare for the community. Small-scale financing restrictions will also affect the repayment of the installment costs. Thus, the characteristics of an easy and no collateral make BWM customers learn the importance of commitment and discipline with a joint responsibility model. The existence of the BWM Pesantren Buntet has played a considerable role in improving the economy of the community surrounding the pesantrens. Customers in pesantrens have a market opportunity with a large number of santri supported by pesantren rules that do not allow students to leave the neighborhood of pesantren. However, not all people know the function and benefits of BWM. This is due to the lack of socialization and education about BWM to the wider community.

The funding used to meet the operational costs of the BWM of the Pesantren Buntet comes from donors who donated funds at LAZMU BSM of 4.25 billion (Fauziah, 2018). The funds are then disseminated in 
three ways, the first three billion rupiah is used as an endowment in the BSM deposit and the profit sharing from the deposit is used for BWM operational costs. Secondly, one billion rupiah has been used for working capital which has stored in BSM savings with a disbursement process every 100 million rupiah. Nowadays, BWM of the Pesantren Buntet has disbursed funds twice with a total of 200 million rupiah, although it appears that the total fund does not large, but problems arise when the demand for financing working capital for customers increase. The BWM has urged to withdraw its third working capital fund to become a total financing of 300 million rupiah. The increase in working capital funds has an impact on mentoring tasks and operational costs which have also increased. This is inversely proportional to the reduced deposits, so that the profit sharing from deposits used for operations also decreases. The amount of working capital incurred causes an imbalance between more and more mentoring tasks with a small number of BWM escorts/ administrators and increasing operational expenses with fewer sources of operational income. (Nasrullah, 2019)

\section{Some Creative Economic Stories}

There are several factors in the development of creative economy in pesantrens, namely traditional embedded values, technological resources and the role of clerics involved in the process of creative economics (Bawono, 2018). In addition, all elements of society such as santri, instructors, the leaders of pesantrens and the community around the pesantren also participate in building the creative economics of the pesantren. With the programs proposed by the pesantren leaders or the government, they can open the way for pesantrens as one of the institutions not only acting as an educational and spiritual religious institution, but also struggle, social and economic institutions. One instrument that forces the pesantren's creative economics run well is the participation of santri in carrying out economic 
activities. Pesantren as educational institutions have roles and functions to carry out academic and non-academic tasks, so they can form students who have the capacity and capability to strengthen in terms of cognitive, effective and psychomotor which is directly beneficial to residents.

The BWM of Pesantren Buntet managers have lead by professionals with a minimum of two years' experience in the field of economics, "Ustadz Aji who has been experienced the world of the economy and even banking for years was chosen," said Ustadz Agus. His role as a kyai and actively involved in economic activities in this institution promote the BWM well developed. Another support given by the kyai as chairman of the BWM was by giving students the opportunity to develop skills/ expertise in the field of economics by involving pesantren students in BWM activities as supervisors. In addition, several students around the pesantren were also given the opportunity to undergo field work practices at the BWM to prepare human resources who were ready to take part in the community, especially in the economic field. These matters were carried out by the pesantren as an effort to equip the santri with various skills to face life's challenges and be more independent. According to Halim (2005), the role of pesantren culminates in three main functions that are always carried out, namely as a cadre of center of excellence, as an institution that prepares human resources and as an institution that has empowered the community. The pesantren is also understood as a part of the process of social change.

These three values are the focus of the BWM of the Pesantren Buntet that enforces this institution gets involved in community empowerment. It is hoped that by implementing a creative economy, creative individuals will be able to create new goods and services. It will produce entrepreneurs who are independent and able to compete in the business world. In addition, entrepreneurs are expected to be able to open new jobs as their contribution to reducing unemployment that is increasingly complex in Indonesia. The 
presence of BWM as an LKMS in the pesantren environment has received a positive response from the community which has been far from the access of financial institutions. Based on the field observations, we found several speakers who had benefited from the BWM program, including Ms. Etty, Ms. Thayyibah, and Ms. Ella. Ms. Etty, a warungan trader who joined BWM since October 2017.

Etty's mother felt very helped by the capital provided. Mrs. Etty has received three installments from the BWM with an initial capital of one million rupiah, which was then continued with capital withdrawal of two million rupiah. The daily income received by Etty is 700 thousand rupiah allocated to the needs of household consumption and savings and repayment funds for the BWM loans. During two years of receiving financial assistance from the BWM Buntet, the business run by Mrs. Etty began to gradually improve. Initially only opened snacks for santri children during school hours and now his business extends to small food shops which are quite helpful for his economy. The increasing effort of Mrs. Etty requires additional loan funds to be able to enlarge the business that has been carried out previously. It is a big expectation for Mrs. Etty that the BWM can increase loans by more than two million rupiah. In addition to the need for additional capital, with the development of the business being run, Mrs. Etty believes that an enlarged business place is needed for the smooth running of the business.

Ms. Thayyibah, a widow with one child, has been a BWM member for more than one year with two installments. The first is one million and the second is two million rupiah. The first installment, Mrs. Thayyibah sells various kinds of breakfast such as yellow rice, fried rice, white rice, snacks and drinks together. In the second installment, he can add merchandise with fruit types. In addition to being a BWM customer, Ms. Thoyibah once joined a similar MFI to finance her business capital, 
but the complexity of regulations was determined such as the obligation to read Pancasila, compulsory collateral and a substantial 10-15 percent profit sharing became a burden on her. Although the initial funding provided by BWM was in a small nominal value, in terms of regulations, the location of BWM and the percentage of profit sharing charged was very helpful in developing its business. Mrs. Thayyibah is very dependent on the environment of the pesantren, while the santri on vacation and no teaching and learning process has an impact on their income which has dropped dramatically. In fact, he compared the location when selling in Bima, Cirebon City, which is a place of visit with the pesantren. He revealed that the market potential in pesantren was more promising, because there were a large number of kyai and each kiyai had a large number of santri.

Another BWM member named Ms. Ella, a grocery store owner and a member of the women's community of recycled plastic used as bag, wallet and carpet. Ms. Ella has started her grocery business for many years and is active in the community of artisans who have empowered village women, then last year she joined the BWM and has received funding twice with one million rupiah each. Ms. Ella is one of the representatives of the the BWM Buntet who is trusted to show her unique results during the BWM customer gathering held by the OJK in January 2019. The results of the business carried out are quite good changes in the economy compared to before being funded by the BWM. In the beginning, joining the craftsmen community was only to fill the void, but at this time the community of craftsmen began to take seriously to see the increasingly promising market results. This makes the community more active in exploring creativity in order to develop the business being run.

Regarding the role of the BWM management in its contribution to member, in being charge of providing facilities to customers, they also played a role in guiding the course of the business while collaborating 
with the BWM Pesantren Buntet. Ms. Ella as the chairman of the HALMI group and having four people who experienced problems often did not attend HALMI, which resulted in the difficulty of returning the funds. This has become the stipulation of BWM that every member must be present at HALMI and make a repayment deposit at the time of the activity. The system carried out by BWM has been more tolerating customers who have repayment constraints but are still present at HALMI rather than being constrained by attendance even though the repayment of the loan is well deposited. Because since the beginning of funding it has been emphasized that discipline and commitment are other substitutes of collateral. If discipline and commitment in the initial financing period are problematic, then this will also have an impact on further financing. The joint responsibility system implemented by the pesantren has positive and negative impacts on the BWM members and customers, as happened to Ms. Ella who had to suffer the consequences. Subsequent fund disbursements which should have reached two million rupiah, Mrs. Ella only received a maximum of one million rupiah in funding, due to the undisciplined members. Of course, the BWM administrators can take steps by having a special approach to customers who lack discipline present at HALMI, the management also takes responsibility in the way of funding.

\section{Being Sharia Micro Finance}

Microfinance Institutions (MFIs) were established specifically to provide business development and community empowerment services, both through loans and financing in micro-scale businesses to members and communities, deposit management and the provision of business development consulting services that are not solely for profit (OJK, 2015). MFIs can be grouped into: 1) formal MFIs, consisting of bank and nonbank units (cooperatives, pawnshops) 2) non-formal MFIs, both legal 
entities (foundations) and those that have not 3) MFIs formed through government programs, 4) MFIs informal, such as social gathering, and loan sharks (Usman et all, 2004).

Microfinance is the most effective tool for fighting poverty, when strategies to increase capital access and programs that can build social communities and increase their capacity can be well integrated (Marco, 2013). The main purpose of microfinance is to reduce poverty and make the poor able to empower themselves actually in line with the principles of justice in the Islamic economy (Rahman, 2007). In Indonesia, in addition to standing microfinance institutions, there are also Lembaga Keuangan Mikro Syariah (LKMS) or Sharia Microfinance Institutions that can be chosen by Muslim communities to gain access to capital in proposing micro-scale financing. Basically, LKMS has a system that is similar to a general MFI. However, the difference is the product and service and the agreement (contract). LKMS places more emphasis on Islamic law, namely the absence of usury, speculation, gharar and dharar fraud. It is different from conventional MFIs that apply the interest system and have an element of usury. LMKS uses a scheme that complies with sharia rules such as qard hasan, murabahah with bai-bithaman-ajil, ijarah, bai-salam and others.

LKMS products and services are known as micro credit. Microcredit in LKMS is an alternative to microcredit offered by conventional MFIs; however, not only in the form of micro-credit, but also providing other products, namely, micro-savings, micro-lease, and micro-insurance (Abdelkader, 2013). Micro-savings is a savings storage product that is categorized as an investment for LKMS. They invest through deposits based on the principles of Islamic law (sharia). Micro-lease is a contract to rent something in a certain time-period. While micro-takaful or micro-insurance is an insurance for the poor in the form of protection for customers from 
unpredictable risks in the form of guarantees. The contract used in LKMS products or services is based on sharia principles which generally also exist in Islamic banking. Among the financing of business cooperation by using musyarakah, mudharabah and other contracts; financing of buying and selling using murabahah, istisna and salam contracts; lease financing using ijarah contract and ijarah muntahiya bit-tamlik. In addition, there are also service products that can be used by the public such as transfers, factoring and others. All these products are carried out using contracts in Islam.

The various LKMS in Indonesia are BMT (BaitulMaal Wattanwil), Sharia Cooperatives, BPRS (Sharia Rural Banks) and BWM (Micro Wakaf Banks). Baitul Mal means a house to collect or store property. BMT is a supporting institution for small-scale economic activities based on the sharia system whose activities develop productive businesses and investments in improving the quality of people's economic empowerment activities (Raharjo, 1999). This institution was established with the intention of facilitating the lower classes of society that is not accessible to the services of Islamic banks or Islamic BPRs (Huda, 2010). In its operations, BMT simply has two main tasks, namely the first Baitul Maal which has a social (non-commercial) vision and mission or more leads to efforts to collect and channel non-profit funds, such as zakat, infaq, and alms. It cannot take any profit from its operations. While operating finance is taken $12.5 \%$ of the total zakat received. Second, Baitul Tamwil which has economic vision and mission in accordance with Islamic economic principles and as an effort to collect and channel commercial funds.

Sharia Cooperatives are commonly called Sharia Savings and Loan Cooperatives (KSPS) or Islamic Financial Services Cooperatives (KJKS) that have different dimensions from conventional cooperatives and BMTs. According to the Decree of the State Minister of Cooperatives and Small and Medium Enterprises of the Republic of Indonesia Number 91 / 
Kep / IV / KUKM / IX / 2004, KJKS is a cooperative whose business activities are in the fields of financing, investment and savings according to the profit-sharing pattern (sharia). Basically, KJKS and BMT are the same because they also have the same legal umbrella, but there are still differences between Sharia Cooperatives and BMTs. BMT functions as two institutions namely Baitul Maal (Zakat Institution) and Baitul Tamwil (Financial Institutions), then KJKS which also carries out the two functions of the institution is called BMT. However, KJKS only functions as a financial institution without acting as a zakat institution, so it is called KJKS or Sharia Cooperative only. Rural Banks (People's Credit Banks) can be understood as Conventional Banks which in their activities do not provide services in payment traffic. (Anonymous, 2011). Whereas in this case, technically a BPRS can be interpreted as a financial institution as a conventional BPR, whose operations follow the principles of Islamic economics (Sjahdeini, 1999). Similar to BPRs, BPRS are prohibited from providing services in payment traffic such as receiving deposit funds in the form of demand deposits even if they are carried out under the wadiah principle.

The BWM fills the existing vacancies from various types of LKMS, Micro Endowment Banks that are not banking institutions and are not under the auspices of Bank Indonesia. BWM is LKMS with business licenses and business models facilitated by OJK. Legally incorporated cooperatives, but its members do not have a stake in determining strategic policies in the management of cooperatives and cannot receive deposits from members such as the types of savings and loan cooperatives in general, the BWM members provide micro loans with very small nominal amounts without collateral, and returns equivalent to 3 percent for operational costs, the BWM has a role to prevent the existence of moneylenders who are still rampant and minimize economic disparities, and maintain an even economic distribution. 
BWM as a Sharia Microfinance Institution (LKMS) reduces several models of microfinance institutions, as according to the Guntz Model (Amalia and Mihajat, 2015), the microfinance model that may be applied by Islamic Financial Institutions is as follows: First, solidarity groups (financing based group) consisting of 4-5 individuals (who know each other) in a group together to obtain financing facilities from Islamic financial institutions. All of them ensure financing recovery and make payments on time in accordance with the predetermined payments according to the schedule (peer monitoring and guarantee mechanism). Secondly, the Grameen Bank Model which is the most well-known business model of microfinance to date that was discovered by Muhammad Yunus, according to him credit is a fundamental human right. This model is allocated to poor and uneducated women in small villages who aim for business and change the social status of the poor to prosperity (Shukran and Rahman, 2011). The difference between BWM and other LKMS can be seen in appendix table 1.1.

The characteristics and benefits of BWM are in line with the legal values of the Islamic Economy which were born and carried out economic activities including business training and assistance as a form of amar ma'ruf nahi munkar, financing of capital business without interest so as to avoid loan sharks. As a form of avoiding usury practices, financing without collateral and implementing a ball picking system, as a form of ta'awun, applying a $3 \%$ profit sharing margin system, reducing poverty as a form of justice for micro-communities and lack of speculation in obtaining assets. Along with the application of Islamic economic values, it will have an impact on increasing Islamic financial literacy and inclusion. The application of Islamic economic values can be seen more clearly in appendix table 1.2. 


\section{BWM in the World Microeconomics}

In the OJK socialization seminar on BWM, Mr. Achmad Buchori, the advisor to the strategic committee and the OJK research center, said that the birth of BWM was inspired by Grameen Bank founded by Muhammad Yunus in Bangladesh. Poor people could fulfill sufficient conditions to apply for bank financing, but This does not mean that poor people do not want to pay their debts if they are given the opportunity, and with this breakthrough it is an achievement that delivered him to the Nobel Prize for World Peace in 2006 (Yunus, 2008). Banks in various worlds began to develop including Indonesia and Malaysia. Malaysia already has AIM (Amanah Ikhtiar Malaysia) which has been operating since 1987. By replicating the Grameen Bank micro credit model in Bangladesh, the AIM program was formed by the Malaysian government with the aim of alleviating poverty based on the Malaysian government's national development policies (Wison, 2007). If Malaysia conducts microfinance in the form of top down, Indonesia conducts microfinance originating from below, namely grassroots (grass root) so that Indonesia has difficulty in developing microfinance. Coupled with the absence of regulatory support and government policies in regulating provisions in a standard manner. But now the Indonesian government is starting to support and pay attention to the development of Islamic Economics along with the development of Islamic products that attract interested people not only Muslim economic actors but non-Muslim economic actors.

In general, AIM and BWM as Microfinance Institutions have many similarities in the system and operational program of providing micro-credit capital, including assistance and empowerment to women. The similarity of Micro Endowment Banks and Malaysian Trustworthiness seen from the target of borrowers is a community with a middle to lower class economy that is not accessible to banking access but requires business 
capital to carry out its economic life. In addition, disbursement without collateral or collateral, funding schemes are carried out with groups and provided with training and assistance every week, no interest and only very low administrative costs are very important values for an institution with the form of Microfinance Institutions. At present, AIM's achievements have also been considerable, including 2013 ASEAN Leadership Rural Award on Rural Development \& Poverty Eradication, 2013 Best Islamic Microfinance Institution, 2014 Best Islamic Microfinance Institution, 2015 Best Islamic Microfinance Institution, 2015 Best Islamic Finance Case, Nobel Laureate winner has managed to provide funding for hundreds of thousands of poor people. Conceptually, the distribution of financing for AIM and BWM has similarities, but several distinguishing points are explained in table 1.3 (in the appendix) and the diversification of AIM financing products is illustrated in table 1.4 (in the appendix).

In Indonesian positive law, an explanation of wakaf already exists with the issuance of several Government Regulations and Laws. However, these regulations regulate to develop assets of goods that are represented not only in the form of movable goods. But goods that move (develop) like money so that the value of money represented can be channeled to productive investment for national development in alleviating poverty and empowering the economy of the community. In the end the government formed the Indonesian Wakaf Agency (BWI) as a wakaf asset manager to achieve national development goals. However, all this time, there have been nadzir wakaf in the form of private bodies or individuals and pesantren and BWI (Gusva et al., 2018). Through the wakaf instrument the government seeks to use it to increase people's income through MSMEs and other investments. In the end in 2017 the government developed the concept of waqf to the Micro Waqf Bank which oversees the income of the middle to lower classes (Maadi, 2018). The financing scheme for micro wakaf banks 
targets the small people with funding that is spent to help micro, small and medium businesses in pesantren and surrounding areas. The money collected at BWM is obtained from donations without being bound. This will potentially develop as the number of Muslims dominates in Indonesia.

BWM funding sources use endowment models, because the investment of money waqf is very potential to be developed in Indonesia. with this waqf model, the range of mobilization will be far more evenly distributed to community members compared to traditional-conventional waqf models, namely in the form of physical assets that are usually carried out by relatively capable families (Ministry of Religion, 2008). The security of this investment covers at least two aspects, first, the security of principal and perpetual values, so that there is no depreciation (a guarantee of integrity). While the second, investment funds can be productive and able to bring results or income (incoming generating allocation). From this income the financing of institutional activities will be carried out and at the same time become a source for the economic development of the people. Through investment, money waqf can be directed at strategic sectors, such as the Micro Credit Sector, the Sharia Financial Portfolio Sector, and the Direct Investment sector. The three sectors are very empowered to boost economic activity and encourage improvement in people's welfare, with a note that all activities in the sector are managed through professional management and political policy support from the government (Kasdi, 2015).

BWM provides micro-credit services, by giving loans with a small nominal with a relatively shorter tenor of return. The very basic difference between microcredit and conventional credit is that borrowers from micro credit are among the poor with low opinions, and focus on women as part of the poorest community, then the difference between micro credit and traditional credit in the form of collateral, micro credit does not require 
collateral, while traditional credit requires collateral (Yunus, 2003). Even though micro credit places collateral with a strategy that is by establishing clients with groups, and being accountable with each other, banks form assistance to control the formation, the potential for pressure in groups helps maintain the transparency of payments for each individual and joint responsibility that functions as social security for loans.

Mentoring is also a key to the sustainability of the BWM business model, for assistance in the establishment of Micro Waqf Banks beginning with the process of establishing legal entities and business permits for Sharia MFIs, management and manager training, operational assistance for at least 6 months and then ready to manage BWM operations. Whereas customer assistance with the socialization of the concept of empowering Sharia MFIs through mentoring and financing, Group Compulsory Training (PWK) for 5 consecutive days, which was filled with material on discipline, cohesiveness, solidarity, courage to try and financial management procedures. Furthermore, the weekly meeting is filled with religious education, business development and household economic management (OJK, 2018). The entrepreneurial knowledge material and business skills needed to operate are forms of education to prospective customers. With this approach, everyone's learning needs are met and empower poor clients to run a sustainable business and above all, these clients can repay loans taken. Even those who cannot be trusted are now responsible borrowers (Hadi et al, 2015).

BWM was directed to improve the financial community in pesantren, but now its establishment has spread to various community communities such as SME mothers and universities. Until the end of December 2018, the OJK has succeeded in facilitating the establishment of BWM in Indonesia. Nationally, from October 2017 to December 2018 the amount of funding successfully channeled by BWM was 9.72 
billion rupiah to 8,373 customers. Each establishment of a BWM unit requires a minimum capital of 4.25 billion rupiah, with an allocation of 250 million rupiah for the initial operational of the institution, 1 billion rupiah is channeled to customers, and 3 billion rupiah is deposited in the bank which will be used to finance operational financing activities. With this system built, February 2018 BWM succeeded in becoming the Quick Wins of the Islamic Financial Sector given by the National Islamic Finance Committee (KNKS).

\section{The Benefits and The Drawbacks}

The BWM has many tasks to improve the system so that the benefits can be maximized. There are also shortcomings in the strengths of the BWM Pesantren Buntet as an example of how BWM works in Indonesia. Among the shortcomings of BWM is the lack of loan funds while customers need funds that vary according to the business that will be carried out. In addition, there are several customers who need funds to develop a business that has been run before. Of course, the maximum funds that can be provided by BWM often do not meet the business needs of the customers. Indirectly this will greatly affect economic development because business creativity has been hampered by the constraints of funding, which is certainly not in line with the objectives of establishing the pesantren. Diverse customer needs with limited BMW products have become a significant problem at the BWM Buntet and need improvement.

In addition, other shortcomings in people's understanding regarding BWM are still minimal, so the presence of BWM as a micro institution that is very close to the community has not yet been felt. There needs to be a socialization of the BWM system and products to the community around the pesantren, on the other hand the BMW boarding school Buntet must continue to strengthen the system and educate the 
management and BMW workers of the Pesantren Buntet. For this reason, we need a method of empowering waqf that is professional, trustworthy, transparent and accountable towards improving the quality and capability of the Nazirites through training, workshops and other activities (Fauziah, 2018).

BWM plays an important role in improving the welfare of its members, both of them hope BWM can open a savings program for members, so that all economic activities that revolve with BWM funds can also be channeled in the form of savings that can be used for future purposes, micro savings has become an aspect forgotten as one of the drivers of financial services provided to disadvantaged communities, the poor cannot reach savings service products in banks for several reasons, including a minimal deposit in deposits, a minimum amount of specified withdrawals, complicated procedures, complex products, lack of supplementary documents, negative views with bank interest among Muslim communities. Micro deposits can be a solution that can deliver so that the community can later meet the criteria of customers of formal financial institutions such as banking. Deposit services also provide a very crucial advantage, which is to give satisfaction to customers' requests for savings, and can provide a lot of financing at low costs (Shariq \& Rahman, 2016). So there is no need to disburse funds to re-develop venture capital financing to new prospective customers, savings from members can be rolled back to other customers who need, BWM financial circulation will become more alive with incoming funds which are then reinvested in the interests of the community.

Diversification of business types also seems necessary to be able to meet all customer needs in accordance with the nominal amount of loans provided and the time required, this needs to be seriously focused so that the effectiveness and development of BWM as a Sharia Microfinance 
Institution can increase more rapidly. The President himself has instructed OJK to be able to add capital loans to customers in accordance with their business prospects, the better the business prospects there are the more liquid funds for financing. The greater the funds provided, the more results obtained, and certainly will have an impact on the development of a larger creative economy (Widodo 2018).

While the advantages of the Micro Wakaf Bank are as a form of economic empowerment in the pesantren environment with a predetermined program and provision, namely close access to the pesantren community, very low profit sharing, a joint responsibility system and picking up the ball, all forms of operations make it very easy customers to be able to expand their business more varied, this was felt by several customers who had previously joined similar MFIs around Cirebon. And since October 2017 Until March 2019 financing at BWM Buntet has run very smoothly. BWM as a micro-product is not impossible to become a bright path for the Indonesian economy, considering the previous micro products such as BMT once engaged in the Islamic economy in Indonesia.

BWM Pesantren Buntet dan BWM diseluruh Indonesia tentunya dapat mewujudkan ini bila secara bersama-sama dapat mempertahankan kelebihan dan memperbaiki kekurangan uang ada serta mewujudkan tujuan awal pembentukan awal BWM. BWM didukung penuh oleh pemerintah dibawah pengawasan kementrian koperasi dan usaha mikro menengah KUMKM yang di sahkan oleh Otoritas Jasa Keuangan (OJK), namun tidak seperti LKMS lainnya yang mampu menyimpan dan mengelola dana dari luar, BWM hanya bisa menyalurkan pembiayaan seperti Lembaga pembiayaan lainnya namun tanpa agunan. OJK akan terus mendorong LKM Syariah di lingkungan pesantren di seluruh Indonesia, program ini diharapkan akan efektif mendukung program pemerintah untuk pemerataan kesejahteraan, khusus pesantren, dan diharapkan menjadi salah satu program unggulan dari KNKS (Santoso, 2017). 


\section{Conclusion}

One of the main functions of pesantren is an institution that has the power to empower the community. Pesantren is also understood as part of the process of social change (Social Change) in the midst of the changes that occur. the presence of BWM in several pesantren has provided a new place for both students and communities living in Pesantrens to carry out their economic potential. At present one of the real sectors that is very worthy of being a priority is the creative economy which relies more on the superiority of human resources.

From October 2017 to March 2019, the total number of customers who have been funded by BWM Buntet is 500 people and the number of customers currently being funded as many as 285 with a total funding of 200 million continues to rotate, without any problematic financing when returning to the BWM. Funding provided by BWM provides stimulation to its customers to develop their businesses more varied and creative. However, BWM needs to increase the amount of funding and products to follow customers' needs to make business variations more promising. BWM Pesantren Buntet provides microcredit programs to its customers in the amount of 1-2 million rupiah. BWM plays its role by helping customers to develop their businesses and increase their type of business to be more diverse in accordance with business needs and consumer interests. Indirectly the funding provided by the BWM provides a stimulus for its customers to develop their businesses more varied and creative.

There are many aspects that can take part in building the creative economy of pesantren starting with santri, instructors, leaders of pesantren (kyai) and communities around the pesantren environment. The leader of the Al Inaroh and Al-Hikmah Pesantren who is also the chairman of the Buntet Pesantren BWM provides a forum for students to develop skills / expertise in the field of economics by including them as supervisors. 
BWM is to prepare human resources who are ready to take part in the community, especially in the economic sector.

The creative economic potential of Pesantren Buntet is actually more than what is seen and running to date, the demand from customers to increase the amount of funding also increases, so from here there is a need to consider variations for programs that have more promising business potential, by providing diversification in accordance with the business carried out, then this will have an impact on the results of the business and give influence to the development of the creative economy that has been running. In addition, customers also want the opening of savings, which on a macro basis this savings loan also has a considerable impact, to strengthen the process of community development and for the poor also functions as a substitute for insurance, deposits also foster austerity and discipline that can increase credit worthiness depositors and can reduce their debt costs.

After seeing some of the potential and developments of BWM from the views and responses of the community, OJK as a determinant of BWM policy is deemed necessary to optimize what must be done for further development of BWM, including receiving deposit funds and diversifying business programs offered. By opening the form of optimization, this can make the creative economy that already exists in the pesantren can grow bigger. The potential and enthusiasm of the BWM community and customers must be facilitated and appropriate by BWM. In addition, by providing deposit taking indirectly this can also be an alternative solution to the BWM system, which is making it a very minimal source of funds for funding sources.

The form of program diversification can also be tailored to the needs of each customer. The distribution process and programs that accommodate the marketing of customers' products also need to be done 
in addition to motivating customers to develop their businesses, they can also help customers market their products. There is a need for a Micro Wakaf Bank Website, in the digital era the use of the internet can also open existing markets, by displaying unique results so that the wider community can access them well. so that all developments and distribution of creative economic results can be accessed more easily by outside the boarding school. 


\section{References}

A. Halim. (2005). Menggali Potensi Ekonomi Pondok Pesantren. Yogyakarta: Pustaka Pesantren.

Amalia, Euis and Mihajat, Muhammad Iman Sastra. (2015). Micro Financing Products and Business Model of Islamic Micro Fiance Institution (Imfis) In Indonesia: Lessons from Baitul Maal Muamalat (BMM), European Journal of Business and Management, Vol. 7 No. 16. Anonymous. (2011). Undang-Undang RI tentang Perbankan Syariah. Yogjakarta: Pustaka Mahardika

Azra, Azyumardi. (2002). Islam Nusantara: Jaringan Global dan Lokal. Bandung: Mizan.

Badan Pusat Statistik and Be Kraft. (2016). Profil Usaha/Perusahaan 16 Subsektor Bekraf Berdasarkan Sensus ekonomi 2016 (SE2016).

Bakar, Abu Sadiq Usman, Rosmaini Tasmin. (2016). The Role of Islamic MicroFinance in Enhancing Human Development in Muslim Countries. Journal of Islamic Finance, Vol. 5 No.1, pp. 53-062

Ben Abdelkader, Ines dan Asma Ben Salem. (2013). Islamic vs Conventional Microfinance Institutions: Performance Analysis in MENA Countries. International Journal of Business and Social Research (IJBSR), Vol. 3, No. 5, pp. 219-233.

Bawono, Anton. (2018). Creative Economic Development of Pesantren. Shirkah Journal of Economics and Business Vol.3 No. 1.

Departemen Agama. (2008). Pedoman Pengelolaan Wakaf Tunai. Jakarta: Direktorat Wakaf.

Dhofir, Zamachsyari. (1982). Tradisi Pesantren: Studi Tentang Pandangan Hidup Kiai. Jakarta: LP3ES.

Falikul, Muhammad Isbah. (2016). Examining the Sosio-Economic Role of Islamic Boarding Schools (Pesantren) in Indonesia. Dissertation, School of Humanities and Social Sciences, UNSW Canberra, Australia 
Fatwa DSN-MUI No. 01/DSN-MUI/IV/2000

Fauziah, Ani. (2018). Bank Wakaf Mikro dan Pengaruhnya terhadap Inklusi Keuangan Pelaku Usaha Kecil dan Mikro (UKM). Surabaya $2^{\text {nd }}$ Proceedings Annual Conference for Muslim Scholars.

Fauziah, Ani. (2018). Peran Bank Wakaf Mikro dalam Upaya Memperkuat Ekonomi Kerakyatan. Prosiding Temu Ilmiah Nasional. Jakad Publisher. Hadi, Rizali dkk. (2015). Education and Microfinance: an Alternative Approach to the Empowerment of the Poor People in Indonesia, Springer Open Journal.

Haidari, Amin dkk, (2004). Masa Depan Pesantren dalam Tantangan Modernitas dan Tantangan Kompleksitas Global. Jakarta: IRD Press.

Huda, Nurul dan Mohamad Heykal. (2010). Lembaga Keuangan Islam: Tinjauan Teoritis dan Praktik. Jakarta: Prenada Kencana Media Group.

Kasdi, Abdurrahman. (2015). Model Pengelolaan Wakaf Produktifal-Azhar Asy-Syarif Cairo Mesir. Yogyakarta: Idea Ekspres.

Maadi, Alan Suud. (2018). Instrumen Bank Wakaf Mikro: Alternatif Pemberdayaan Ekonomi Pesantren. Second Proceedings Annual Conference for Muslim Scholars.

Madekhan (2016)., Tiga Model Peran Strategis Pesantren Di Indonesia, Reforma Jurnal Pendidikan \& Pembelajaran, retrieved from http:// jurnalpendidikan.unisla.ac.id/index.php/reforma/issue/view/1

Mastuhu. (1994). Dinamika Sistem Pendidikan Pesantren. Jakarta: KINIs.

Moelyono, Mauled. (2010). Menggerakkan Ekonomi Kreatif Antara Tuntutan, Jakarta; Rajawali Press.

Nasrullah, Agus. (Interview, 2019. 27 April).

Nadzir, Muhammad. (2015). Membangun Pemberdayaan Ekonomi di Pesantren. Jurnal Conomica, Volume VI, Edisi 1, Mei.

Noviyanti, Ririn (2017). Peran Ekonomi KreatifTerhadap Pengembangan Jiwa Entrepreneurship di Lingkungan Pesantren, Jurnal Penelitian Ilmiah Intaj. 
Pangkalan Data Pondok Pesantren (PDPP) retrieved from http://pbsb. ditpdpontren.kemenag.go.id/pdpp/

Peraturan Otoritas Jasa Keuangan Nomor /Pojk.05/2014 tentang Penyelenggaraan Usaha Lembaga Keuangan Mikro.

Peraturan Otoritas Jasa Keuangan Nomor 3/Pojk.03/2016 tentang Bank Pembiayaan Rakyat Syariah

Raharjo, M. Darmawan. (1999). Islam dan Tantangan Transformasi Sosial Ekonomi. Jakarta: Lembaga Studi Agama dan Filsafah

Rahman, Abdul and Rahim, Abdul. (2007). Islamic Microfinance: A missing component in Islamic Banking. Kyoto Bulletin of Islamic Area Study 1-2, pp. 38-53.

Revindo, Mohamad D. and Gan, Christropher. (2017). Microfinance Institutions in Malaysia, in Christropher Gan and Nartea Gilbert, Microfinance in Asia. World Scientific.

Santoso, Wimboh. (2017). Pemaparan Ketua OJK saat Pengesahan 10 BWM di Cirebon.

Sjahdeini, Sutan Remy. (1999). Perbankan Islam dan Kedudukannya dalam Tata Hukum Perbankan Indonesia, Jakarta: Pustaka Utama Grafiti

Shariq and Syed Mizanur Rahman. (2016), Minority Funds in India Institutional Mobilizing of Micro Saving. Sharia Compliance.

Shukran, Khaled dan Farhana Rahman, (2011). A Grameen Bank Concept: Micro-credit and Poverty Alleviation Program in Bangladesh, International Conference on Emerging Trends in Computer and Image Processing (ICETCIP) Bangkok. pp. 47-51

Srimulyani, Eka. (2012). Woman and Pesantrens in Jombang: A Potrait from The Fieldwork. Amsterdam: Amsterdam University Press.

Otoritas Jasa Keuangan. (2018). Bank WakafMikro, Program Pemberdayaan Masyarakat melalui Pendirian Bank Wakaf Mikro, Bahan Sosialisasi Publik, Forum Merdeka Barat 9, Jakarta, 27 Maret. 
Turmudi, Endang. (2006). Struggling for the Umma: Changing Leadership Roles of Kiai in Jombang, East Java. Australia: ANU Press.

Tavanti, Marco. (2013). Before Microfinance: The Social Value of Microsavings in Vincentian Poverty Reduction, Journal of Business Ethics. 112, pp. 697-706.

Usman S., dkk. (2004). Kenangan Mikro Untuk Masyarakat Miskin; Pengalaman Nusa Tenggara Timur. Jakarta: Lembaga Penelitian SMERU.

Widodo, Joko. (2018). Interview, Berita Satu, 28 March, retrieved from http://beritasatu.tv

Wison, Rodney. (2007). Making Development Assistance sustainable through Islamic Microfinance. Retrieved from imfea.or.id

Yunus, Muhammad. (2008). Menciptakan Dunia Tanpa Kemiskinan. Jakarta: Gramedia. 


\section{Appendixes}

\section{Table 1.1 Difference between BWM and other LKMS}

\begin{tabular}{|c|c|c|c|c|}
\hline Element & BMT & Sharia Cooperation & BPRS & BWM \\
\hline Business License & $\begin{array}{l}\text { Minister for } \\
\text { cooperatives Small } \\
\text { and Medium } \\
\text { Enterprises } \\
\text { (Kemenkop UKM) } \\
\text { / OJK }\end{array}$ & $\begin{array}{l}\text { Minister for } \\
\text { cooperatives Small } \\
\text { and Medium } \\
\text { Enterprises } \\
\text { (Kemenkop UKM) } \\
\text { / OJK }\end{array}$ & OJK & OJK \\
\hline Legal entity & cooperation & cooperation & $\begin{array}{l}\text { PD } \\
\text { C o m p a n y ), } \\
\text { Cooperative, PT, or } \\
\text { other forms. }\end{array}$ & cooperation \\
\hline Institutional type & Non formal & Formal & Formal & $\begin{array}{l}\text { LKM which formed } \\
\text { through government } \\
\text { programs }\end{array}$ \\
\hline development & OJK & Kemenkop UKM & OJK & OJK \\
\hline Supervision & OJK & Pengawas Internal & OJK & OJK \\
\hline membership & People in general & member & People in general & member \\
\hline Source of funds & Partner & Member & $\begin{array}{l}\text { shareholders } \\
\text { the SRB (not from } \\
\text { loans or financing } \\
\text { facilities in any form } \\
\text { whether banks or } \\
\text { other parties. not } \\
\text { originating from } \\
\text { and for money } \\
\text { laundering) }\end{array}$ & $\begin{array}{l}\text { Eternal social fund } \\
\text { (wakaf) }\end{array}$ \\
\hline Product & $\begin{array}{l}\text { Micro Kredit, Micro } \\
\text { savings, }\end{array}$ & $\begin{array}{l}\text { Micro Kredit, Micro } \\
\text { savings }\end{array}$ & $\begin{array}{l}\text { Micro Kredit, Micro } \\
\text { leasing, }\end{array}$ & Micro Credit \\
\hline Akad (contract) & $\begin{array}{l}\text { LAZ (Amil Zakat } \\
\text { Institution) } \\
\text { Micro saving: } \\
\text { wadiah and } \\
\text { mudharobah. Micro } \\
\text { Credit:Mudharobah, } \\
\text { Musyarakah, Rahn, } \\
\text { Qardh. } \\
\text { Sell ing-B u y ing: } \\
\text { Murabahah, Istishna, } \\
\text { Ijarah, } \\
\text { Stock }\end{array}$ & \begin{tabular}{|l|} 
Micro saving: \\
wadiah and \\
mudharobah. Micro \\
Credit:Mudharobah, \\
Musyarakah, Rahn, \\
Qardh. \\
Selling-buy ing: \\
Murabahah, Istishna, \\
Ijarah, \\
Salam
\end{tabular} & $\begin{array}{l}\text { Micro saving: wadiah } \\
\text { and mudharobah. } \\
\text { Micro Credit: } \\
\text { Mudharobah, } \\
\text { Musyarakah, Rahn, } \\
\text { Qardh }\end{array}$ & $\begin{array}{l}\text { Micro Credit: Qard } \\
\text { Hasan }\end{array}$ \\
\hline Purpose & $\begin{array}{l}\text { Profit and falah } \\
\text { oriented }\end{array}$ & Profit oriented & Profit oriented & $\begin{array}{l}\text { Sosial and profit } \\
\text { oriented }\end{array}$ \\
\hline
\end{tabular}




\begin{tabular}{|c|c|c|c|c|}
\hline $\begin{array}{l}\text { Amount of financing } \\
\text { distribution }\end{array}$ & $\begin{array}{l}\text { Minimum funding is } \\
\text { given } 50,000 \text {. while } \\
\text { the maximum is } 10 \% \\
\text { for group customers. } \\
\text { And for individual } \\
\text { customers, the } \\
\text { maximum is } 5 \% \text { of } \\
\text { the MFI's capital. }\end{array}$ & $\begin{array}{l}\text { Minimum funding is } \\
\text { given } 50,000 \text {. while } \\
\text { the maximum is } 10 \% \\
\text { for group customers. } \\
\text { And for individual } \\
\text { customers, the } \\
\text { maximum is } 5 \% \text { of } \\
\text { the LKM's capital. }\end{array}$ & $\begin{array}{l}\text { Minimum funding is } \\
\text { given } 50,000 \text {. while } \\
\text { the maximum is } 10 \% \\
\text { for group customers. } \\
\text { And for individual } \\
\text { customers, the } \\
\text { maximum is } 5 \% \text { of } \\
\text { the MFI's capital. }\end{array}$ & $1-3$ million \\
\hline $\begin{array}{l}\text { Guarantee } \\
\text { Requirements }\end{array}$ & Guarantee & Guarantee & Guarantee & without Guarantee \\
\hline $\begin{array}{l}\text { Relation with } \\
\text { member }\end{array}$ & Partnership & Creditor-debtor & Membership & $\begin{array}{l}\text { Membership } \\
\text { (partnership) }\end{array}$ \\
\hline
\end{tabular}

Source: Author data processed.

\section{Table 1.2 Islamic Economic Values in BWM}

\begin{tabular}{|c|c|c|}
\hline Characteristic of BWM & $\begin{array}{l}\text { Legal values of Islamic } \\
\text { Economics }\end{array}$ & Program List \\
\hline Business training and assistance & Amar ma'ruf & $\begin{array}{l}\text { HALMI filled with business guidance and } \\
\text { religious activities. }\end{array}$ \\
\hline $\begin{array}{l}\text { Shun the practices of } \\
\text { moneylenders }\end{array}$ & Nahyi Munkar & Interest-free financing. \\
\hline $\begin{array}{l}\text { Business capital financing } \\
\text { without interest }\end{array}$ & $\begin{array}{l}\text { Steer clear of usury } \\
\text { practices /riba }\end{array}$ & Micro financing worth 1-3 million \\
\hline $\begin{array}{l}\text { Financing by forming groups } \\
\text { without collateral }\end{array}$ & Ta'awu (help each other) & $\begin{array}{l}\text { Renteng tanggung which is the principle of } \\
\text { the Islamic economy in the form of social } \\
\text { solidarity. If one body member is sick, the } \\
\text { whole body will feel pain too. }\end{array}$ \\
\hline $\begin{array}{l}\text { Implement a ball picking } \\
\text { system }\end{array}$ & Ta'awun & $\begin{array}{l}\text { supervisor comes to the customer for } \\
\text { repayment }\end{array}$ \\
\hline $\begin{array}{l}\text { Implementation of a } 3 \% \text { profit } \\
\text { sharing margin system and } \\
\text { reducing poverty }\end{array}$ & $\begin{array}{l}\text { Justice and lack of } \\
\text { speculation in obtaining } \\
\text { property }\end{array}$ & $\begin{array}{l}\text { Micro financing is equivalent to } 3 \text { percent } \\
\text { for people who are not touched by banking } \\
\text { access, compared to a } 12 \text { percent margin in } \\
\text { Conventional Banks and loan sharks that } \\
\text { reach } 20-60 \text { percent. }\end{array}$ \\
\hline
\end{tabular}

\section{Source: Author data processed.}




\section{Table 1,3 Different Characteristic Between AIM and BWM}

\begin{tabular}{|c|c|c|}
\hline Characteristic & Waqf Micro Bank & Amanah Ikhtiar Malaysia \\
\hline Established & 2017 & 1987 \\
\hline Administration fee & 50.000 and $3 \%$ each year & $10 \%$ each year \\
\hline Program provided & $\begin{array}{l}\text { 1. Non Deposit Taking } \\
\text { 2. Business capital }\end{array}$ & $\begin{array}{l}\text { 1. Deposit taking } \\
\text { Capital for business, consumptive } \\
\text { needs, education } \\
\text { Alms for customers in need }\end{array}$ \\
\hline Organisation Type & Semi formal & Informal \\
\hline Services area & pesantren & Throughout Malaysia \\
\hline Number of institutions & 41 & 136 \\
\hline Number of customers & 8.373 & 378,721 \\
\hline Amount of funds channeled & 9,72 billion & RM 21,478,004,131 \\
\hline Distribution & surrounding pesantren & All around Malaysia \\
\hline Publication & Accessible trough Website & no website \\
\hline
\end{tabular}

Source: Author data processed.

\section{Table 1.4 Financing Products AIM (Amanah Ikhtiar Malaysia)}

\begin{tabular}{|c|c|c|c|c|}
\hline Type of Loan & & Detail & $\begin{array}{l}\text { Amount } \\
\text { of internal } \\
\text { financing RM }\end{array}$ & Tenor time \\
\hline \multirow[t]{3}{*}{ General } & i-Mesra & $\begin{array}{l}\text { Providing financing that is trusted } \\
\text { to provide a good return }\end{array}$ & $1000-10.000$ & 12-150 weeks \\
\hline & i-Srikandi & $\begin{array}{l}\text { Funding potential customers and } \\
\text { success in the project }\end{array}$ & $12000-20000$ & $12-150$ weeks \\
\hline & i-Wibawa & $\begin{array}{l}\text { Provide additional capital } \\
\text { to continue projects that are } \\
\text { delayed or take advantage of an } \\
\text { opportunity in a short period of } \\
\text { time }\end{array}$ & $5000 \max$ & $\begin{array}{l}6 \text { months of } \\
\text { payment in } \\
\text { installments } \\
\text { each week / } \\
\text { monthly or full } \\
\text { payment }\end{array}$ \\
\hline \multirow[t]{4}{*}{ Social and recovery } & i-sejahtera & Financing for various purposes & $1000-10000$ & $12-100$ \\
\hline & i-bestari & Cost of education & $1000-5000$ & $12-100$ weeks \\
\hline & i-penyayang & $\begin{array}{l}\text { Funding for members who } \\
\text { experience bankruptcy, illness or } \\
\text { disaster }\end{array}$ & $1000-5000$ & 12-100 weeks \\
\hline & i-emas & For the elderly (over 75 years) & $2000 \max$ & $12-50$ weeks \\
\hline
\end{tabular}

Source: Author data processed. 


\section{Shirkah Author Guidelines}

Shirkah currently offers two routes to submit manuscripts. We highly recommend to submit the articles which are made using OJS (Open Journal System). Feel free register as author soon through visiting http:// shirkah.or.id/index.php/home/user/register. The authors may directly send their manuscripts, along with their resume, to shirkahiainsurakarta@ gmail.com. Please prepare your manuscripts, using following guidelines:

1. Manuscript must be written in English. Submitted articles should not have been published or be under review for publication with another journal.

2. Manuscript's length is about $15-20$ pages, typed in one-half spaced on A4-paper size.

3. Manuscript must include an $150-200$ word abstract and keywords.

4. Manuscript must be arranged as follows: Title, Name of Author, E-mail address, Abstract, Keywords, Introduction (including method if any), Discussion, Conclusion, References.

5. Manuscript's titles not more than ten words.

6. Manuscript must be submitted in Microsoft Word or RTF.

7. Arabic words should be transliterated according to the style of International Journal of Middle Eastern Studies.

8. Manuscript references are preferably derived from the up-to-date references.

9. The author's resume should be submitted separately, consisting of at least full name, institutional address, phone number, areas of studies, and recent publications (if any).

10. Shirkab use APA Style 6th edition (2010) as reference format writing. We suggest the use of a reference manager software such as Mendeley, Zotero, and Endnote at templating the citation style. APA Style to be used is as follows: 


\section{Book with single author}

Swann, G. M. Peter. (2014). The Economics of Innovation an Introduction. Cheltenhum \& Northampton: Edward Elgar.

in-text citation: (Swann, 2014)

\section{Articles in reference books}

Alatas, S. F. (2006). Islam and the Science of Economics in Abu Rabi', I.M. The Blackwell Companion to Contemporary Islamic Thought. USA: Willey-Blackwell (pp. 587-606).

in text citation: (Alatas, 2006)

\section{E-Book}

Hackett, Rosalind (2007). "Religous Dimentions of War and Peace: Introduction.” Dalam Gerrie ter Haar dan Yoshio Tsuruoka (Ed.), Religion and Society: An Agenda for the 21st Century (h. 3-6). Retrieved from http:// brill.nl.

in text citation: (Hackett, 2006)

\section{Master's thesis, from a commercial database}

McNieI, D. S. (2006). Meaning through narrative: A personal narrative discussing growing up with an alcoholic mother (Master's thesis). Available from ProQuest Dissertations and Theses database. (UMI No. 1434728)

in text citation: (Mc Niel, 2006)

\section{Doctoral dissertation, from an institutional database}

Adams, R. J. (1973). Building a foundation for evaluation of instruction in higher education and continuing education (Doctoral dissertation). Retrieved from http://www.ohiolink.edu/etd/

in text citation: (Adams, 1973) 


\section{Doctoral dissertation, from the web}

Bruckman, A. (1997). MOOSE Crossing: Construction, community, and learning in a networked virtual world for kids (Doctoral dissertation, Massachusetts Institute of Technology). Retrieved from http:/www-static. cc.gatech.edu/--asb/thesis/

in text citation: (Bruckman, 1997)

\section{Journal article with No DOI}

Bourkhis, K., and Nabi, M. S. (2013). Islamic and conventional banks' soundness during the 2007-2008 financial crisis. Journal Metrics, 22(2), 68-77.

in-text citation: (Bourkhis \& Nabi, 2013).

\section{Journal article with DOI}

Ichwan, M. (2012). The Local Politics Of Orthodoxy: The Majelis Ulama Indonesia in the Post-New Order Banten. Journal Of Indonesian Islam, 6(1), 166-194. doi:http://dx.doi.org/10.15642/JIIS.2012.6.1.166-194

In text citation : (Ichwan, 2012)

\section{Abstract as citation}

Hasan, N. (2012). Islamist Party, Electoral Politics And Da'wah Mobilization Among Youth : The Prosperous Justice Party (PKS) in Indonesia. Journal of Indonesian Islam, 6(1), 17-47. Abstract from http:// jiis.uinsby.ac.id/index.php/jiis/article/view/97

in text citation : (Hasan, 2012)

\section{Mass media article}

Sahal, Akhmad (2014, March 2). Kiai Sahal dan Realisme Fikih.Tempo Magazine, p. 120.

in text citation : (Sahal, 2014) 


\section{Research report}

Fisher, B. S., Cullen, F. T., \& Turner, M. G. (2000). The Sexual Victimization of College Women. Research Report.

in text citation : (Fisher, Cullen, Turner, 2000)

\section{Monograph}

Routray, Bibhu Prasad (2013), National Security Decision-Making in India (RSIS Monograph No. 27). Singapura: Rajaratnam School of International Studies.

in text citation : (Routray, 2013)

\section{Proceeding article}

Sudibyakto, Hizbaron, D.R., \& Jati, R (Ed.) (2009), Proceeding International Seminar Disaster Theory, Research and Policy. International seminar held by Sekolah Pascasarjana, Universitas Gajahmada, Yogyakarta, 8-9 Desember 2009.

in text citation : (sudibyakto and Jati, 2009)

\section{Paper conference/seminar/symposium}

Janutama, Herman Sinung (2011). "Kraton dan Hubungan Antar Agama." Paper presented in Seminar Kraton dan Panatagama held by Center for the Study of Islam and Social Transformation (CISForm), Yogyakarta, 17 November.

in text citation :(Janutama, 2011)

\section{Online article in web}

Shiva, (2006, February). Bioethics: A Third World Issue. Native-web. Diperoleh dari http://www.nativeweb.org/ pages/legal/shiva.html

in text citation : (Shiva, 2006) 


\section{Online research report}

Kessy, S. S. A., \& Urio, F M. (2006). The contribution of microfinance institutions to poverty reduction in Tanzania (Research Report No. 06.3). Retrieved from Research on Poverty Alleviation website: http://www. repoa.or.tz /documents_storage/Publications/Reports/06.3_Kessy_and_ Urio.pcif

in text citation : (kessy and urion, 2006)

\section{Holy book}

Qur an, $2(25)$

In text citation : (Q. al-Baqarah 2:25).

\section{Encyclopaedia}

Graycar, Adam (1992). Social Welfare Policy. Dalam Mary Hawkesworth dan Maurice Kogan (Ed.), Encyclopedia of Government and Politics (Vol. 1). London: Routledge.

in text citation : (Graycar, 1992)

\section{Interview}

Sultan Hamengkubuwono X (interview, 2011, April 19)

in text citation: (Hamengkubuwono, 2011)

\section{Documentary film}

Steijlen, Fridus (2008). A Day in the Life of Indonesia [documentary film, 58 minutes]. Leiden: KITLV Press.

in text citation : (Steijlen, 2008) 
Vol. 4 No. 2, May - August 2019 